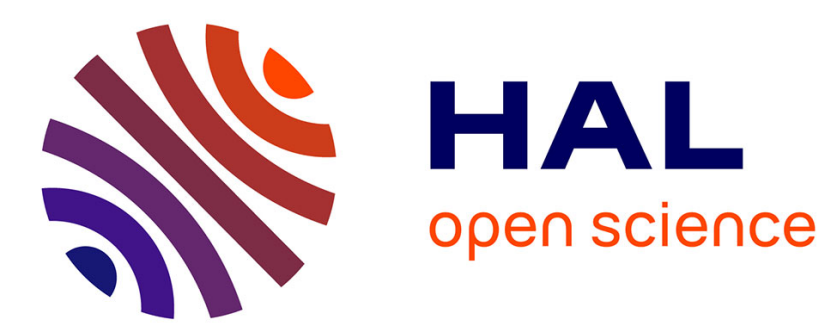

\title{
De Gaulle as a Father of Europe: The Unpredictability of the FTA's Failure and the EEC's Success (1956-58)
}

Laurent Warlouzet

\section{To cite this version:}

Laurent Warlouzet. De Gaulle as a Father of Europe: The Unpredictability of the FTA's Failure and the EEC's Success (1956-58). Contemporary European History, 2011, 20 (4), pp.419-434. 10.1017/S0960777311000464 . hal-02610169

\section{HAL Id: hal-02610169 \\ https://hal.science/hal-02610169}

Submitted on 13 Aug 2020

HAL is a multi-disciplinary open access archive for the deposit and dissemination of scientific research documents, whether they are published or not. The documents may come from teaching and research institutions in France or abroad, or from public or private research centers.
L'archive ouverte pluridisciplinaire HAL, est destinée au dépôt et à la diffusion de documents scientifiques de niveau recherche, publiés ou non, émanant des établissements d'enseignement et de recherche français ou étrangers, des laboratoires publics ou privés. 


\section{De Gaulle as a Father of Europe The Unpredictability of the FTA's Failure and the EEC's Success (1956-58)}

\section{LAURENT WARLOUZET}

Version auteur de l'article publiée avec le titre:

Laurent Warlouzet, " De Gaulle as a Father of Europe: The Unpredictability of the FTA's failure and the EEC's Success (1956-1958) », in Contemporary European History, 20, 4, 2011, pp. 419-434.

DOI: https://doi.org/10.1017/S0960777311000464

Pour une mise à jour historiographique de l'argumentation:

Laurent Warlouzet, Governing Europe in a Globalizing World: Neoliberalism and its Alternatives following the 1973 Oil Crisis, London, Routledge, 2018, 274 p.

\section{Abstract}

The failure of the Free Trade Area (FTA), a British 'Greater Europe' free-market project, has often been contrasted with the European Economic Community (EEC)'s rapid success. However, this article claims that the EEC's success was neither logical nor automatic. The FTA project was not bound to failure, but could easily have become the principal institution for European co-operation. Moreover, the French leader, Charles de Gaulle, played such a prominent role in the EEC that he could be described as a new 'Father of Europe'. Without the EEC, France would certainly have been forced to reach agreement on the FTA, but conversely, without de Gaulle, the EEC would probably have been diluted into a larger FTA.

Establishing a free trade area in Europe had been a long-standing objective for many Europeans, and particularly for the British, at least from the time that Keynes proposed such a scheme in 1919. 'The term 'Free Trade Area' (FTA) was adopted as the title of an important European co-operation project, which was launched by the British in 1956, but which had failed by 1959 . During this same period, the $\mathrm{Six}^{2}$ signed the Treaty of Rome (1957), and thus created the European Economic Community (EEC), which quickly became the main organisation for European co-operation. This article asserts that the EEC's success was neither logical nor automatic. On the contrary, it argues, first, that the FTA project was not bound to failure but that the FTA could have become the principal institution for European co-operation, and, second, that the French leader, Charles de Gaulle, played such a prominent role in the EEC that he could well be described as a new 'Father of Europe'.

\footnotetext{
${ }^{1}$ John Maynard Keynes, The Economic Consequences of the Peace (London: Macmillan, 1971; 1st ed., 1919), 168.

${ }^{2}$ The 'Six' refers to the six founding countries of the EEC in 1957: Belgium, the Federal Republic of Germany, France, Italy, Luxembourg and the Netherlands.
} 
In this context, 'Europe' means 'European integration', that is to say, the process of building a semi-federal, or supranational, organisation with the specific aim of bringing European states and people closer. On the other hand, the FTA represents the embodiment of the long-term project to build a 'Greater Europe' with intergovernmental institutions, but without any specific European perspective since the various European organisations could easily be considered as just temporary steps towards an international solution. Thus, the period from 1956 to 1958 is of crucial importance because supranational Europe took precedence over 'Greater Europe', whereas historically the idea of a 'Greater Europe' had been much more predominant. De Gaulle played - partly unintentionally - a greater role in the assertion of a supranational Europe than many of the other figures, such as Altiero Spinelli, ${ }^{3}$ or even Jean Monnet (who only played a secondary role in the creation of the EEC), ${ }^{4}$ who are so revered by EU institutions. He therefore does deserve the title 'Father of Europe', even though he did not share the enthusiasm for the EEC of others, such as Schuman, Adenauer, Spaak and De Gasperi, who are more usually associated with this distinction. ${ }^{5}$

This paper is based on the three primary sources of the British, French and EEC archives, ${ }^{6}$ and will first examine the historiography of the failure of the FTA in order to demonstrate its limitations. Two sections will then describe the issues in question, first by comparing the EEC and the FTA, and second by explaining the central part played by France in these negotiations. The focus will then shift to de Gaulle so as to account for his initial support for and subsequent rejection of the FTA. A final section will deal with the lessons learned by the FTA's failure.

\footnotetext{
${ }^{3}$ For example, the main building of the European Parliament in Brussels is named after Altiero Spinelli.

${ }^{4}$ Monnet was more interested in Euratom than in the future EEC during all the negotiations of the Treaties of Rome. He therefore played a limited role in the discussions leading to the creation of the EEC in March 1957: François Duchêne, Jean Monnet: The First Statesman of Interdependence (New-York: Norton, 1994), $292,306$.

${ }^{5}$ Robert Frank, 'Les pères de l'Europe: Une difficile typologie', in Paul Smets, ed., Les Pères de l'Europe: cinquante ans après. Perspectives sur l'engagement européen (Bruxelles: Bruylant, 2001), 13-26.

${ }^{6}$ For more details, see Laurent Warlouzet, Le choix de la CEE par la France. L'Europe économique en débat de Mendès-France à de Gaulle (1955-1969) (Paris: Cheff, 2011). In the footnotes, AFFAM is used for the Archives of the French Foreign Affairs Minister, AFMF for the archives of the French Minister of Finances, DDF for Documents diplomatiques français (published documents of the French Foreign Affairs minister), EUA for the European Union Archives (in Brussels), FNA for the French National Archives, TNA for the British National Archives.
} 


\section{The Historiography of the FTA's Failure}

The FTA negotiations have been thoroughly investigated by historians, ${ }^{7}$ who have made use of two early seminal publications by the journalist Miriam Camps ${ }^{8}$ supporting the view of a 'French veto' against the FTA. From the French point of view, the FTA negotiations have been less systematically analysed. The most valuable contributions come from two specialists on the history of France, Gérard Bossuat ${ }^{9}$ and Frances Lynch, ${ }^{10}$ from Alan Milward's study on the UK, and from Andrew Moravcsik's renowned and provocative book on European integration history. ${ }^{11}$ This paper complements and sometimes contradicts this literature by emphasising three points.

The first point concerns the fact that the FTA is sometimes portrayed as a project which was doomed to failure as soon as de Gaulle regained power in June 1958. Milward clearly explains that 'With the collapse of the Fourth Republic and General de Gaulle's return to power in Paris in July 1958 after eleven years, the government of the new Fifth Republic took a firm decision against commitment to the free-trade area proposal'. ${ }^{12}$ Gérard Bossuat argues that the FTA was 'condemned' as soon as de Gaulle drew closer to Adenauer on 14 September 1958. Frances Lynch states that de Gaulle rejected the FTA very soon after his return to power. ${ }^{13}$ However, this article will show that until October 1958, de Gaulle was ready seriously to commit himself to FTA negotiations, provided that the result was minimalist and that such a result was reached after the EEC became fully functional - in 1959 at the earliest. If the French leader did indeed break off the negotiations, it was because of British errors of strategy, and this fact gives rise to a more nuanced impression of the 'French veto'.

De Gaulle's policy towards the FTA is also frequently associated with that of his predecessors. Gérard Bossuat, in particular, has stressed the continuity between the French memorandum of February 1958 on the FTA, which was drafted during the period of the Félix Gaillard government, and de Gaulle's position. ${ }^{14}$ Despite the fact that the main reasons for France's opposition to the FTA remained the same, de Gaulle's government broke with the previous government's policy as it adopted a strategy of greater collaboration with its

\footnotetext{
${ }^{7}$ James Ellison, Threatening Europe: Britain and the Creation of the European Community, 1955-1958 (NewYork: St Martin's Press, 2000); Wolfram Kaiser, Using Europe, Abusing the Europeans: Britain and European Integration, 1945-1963 (Basingstoke: Macmillan Press, 1996); Alan S. Milward, The Rise and Fall of a National Strategy, 1945-1963 (London: Whitehall History Publishing, 2002).

${ }^{8}$ Miriam Camps, The Free Trade Area Negotiations (London: Political and Economic Planning, 1959); Camps, Britain and the European Community, 1955-1963 (Princeton: Princeton UP, 1964).

${ }^{9}$ Gérard Bossuat, Faire l'Europe sans défaire la France. 60 ans de politique d'unité européenne des gouvernements et des présidents de la République française (1943-2003) (Brussels: PIE-Peter, 2005); Gérard Bossuat, 'La France et la zone de libre-échange. Le jeu du pouvoir politique et des intérêts économiques (19561959) ', in Andrea Ciampani, L'altra via per l'Europa: Forze sociali e organizzazione degli interessi nell'integrazione europea (1947-1957) (Milan: F. Angeli, 1995), 350-82; Gérard Bossuat, L'Europe des Français, 1943-1959. La IVe République aux sources de l'Europe communautaire (Paris: Publications de la Sorbonne, 1996).

${ }^{10}$ Frances Lynch, 'De Gaulle's First Veto: France, the Rueff Plan and the FTA', Contemporary European History, 9, 1 (2000), 111-35.

${ }^{11}$ Andrew Moravcsik, The Choice for Europe: Social Purpose and State Power from Messina to Maastricht (London: UCL Press, 1999).

${ }^{12}$ Milward, Rise and Fall, 266, see also 288.

${ }^{13}$ Lynch, 'De Gaulle', 121, 134. The quotation comes from p. 134.

${ }^{14}$ Bossuat, Faire l'Europe, 79; Bossuat, 'Le choix de la petite Europe', 218, 220-21; Bossuat, 'La France et la zone de libre-échange', 365 .
} 
European partners. As a result of this strategic shift on technical but decisive points, the French FTA policy became much more credible than before.

Lastly, the French motivation in rejecting the FTA is frequently explained by agricultural policy-related problems. The FTA did indeed seem to offer fewer prospects for French agricultural exports than the EEC. In particular, Andrew Moravcsik made the provocative statement that de Gaulle's European policy was entirely driven by his aim of promoting French agricultural exports, ${ }^{15}$ and indeed criticisms of this assertion have been discussed elsewhere. ${ }^{16}$ This paper will concentrate on the reasons why France and de Gaulle rejected the FTA, and will demonstrate that the agricultural issue played only a secondary role in this rejection.

\section{The FTA's Strengths and Weaknesses Compared to Those of the EEC}

Two distinct complementary forms of European co-operation were developed after $1945 .^{17}$ On the one hand, the creation in 1948 of the Organisation for European Economic Cooperation (OEEC) covered seventeen western European states. The OEEC's institutions were intergovernmental, and most of their powers remained under the control of the member states. This could well be associated with the 'free-market Europe' vision promoted during the interwar period, particularly by Keynes in 1919. On the other hand, a small group of countries, the 'Six' until 1973, had become involved in a more ambitious and dynamic development, in which prominence was given to semi-federal institutions and more elaborate tools of economic co-operation. The European communities - the European Coal and Steel Community (ECSC, 1951) and, later, the European Economic Community (EEC, 1957) embodied this ambition to develop a more proactive or organised vision of European cooperation.

As 'community Europe' finally took the lead in the 1960s, it was more or less confused with the expression 'European integration', and subsequently with the notion of 'Father of Europe'. However, it is frequently forgotten that for a long time the liberal form of cooperation had been the most important, with the most important European co-operation projects discussed during the inter-war period not entailing any supranational dimension. In 1948, the OEEC was the first European co-operation organisation, and in 1950 it was accompanied by a sister organisation for monetary co-operation, the European Payment Union (EPU). In contrast, the development of 'community Europe', after a bold start in 1951 with the establishment of the ECSC, was at a standstill because of the failure of the European Defence Community (EDC) in 1954, the incapacity of the ECSC to generate momentum towards greater integration, and the deadlock of the negotiations on numerous projects of sectoral co-operation designed to complement the ECSC, such as the 'green pool' on agriculture, and the 'white pool' on pharmaceutical products. ${ }^{18}$ The initiative resumed in

\footnotetext{
${ }^{15}$ Moravcsik, The Choice, 177, 182-4.

${ }^{16}$ Laurent Warlouzet, 'The deadlock: the choice of the CAP by de Gaulle and its impact on French EEC policy, 1958-1969', in Kiran Patel, ed., Fertile Ground for Europe? The History of European Integration and the Common Agricultural Policy since 1945 (Baden-Baden: Nomos, 2009), 99-118.

${ }^{17}$ On the opposition between the two models of Economic Europe: Laurent Warlouzet, 'Les identités économiques européennes en débat dans les années soixante: Europe arbitre et Europe volontariste', Relations internationales, 139 (2009), 9-23.

${ }^{18}$ Tobias Witschke, Gefahr für den Wettbewerb? Die Fusionkontrolle der Europaïschen Gemeinschaft für Kohle und Stahl und die 'Rekonzentration' der Ruhrstahlindustrie, 1950-1963 (Berlin: Akademie Verlag, 2009); for the failure of the various projects of sectoral European co-operation, see Pierre Gerbet, La naissance du marché commun (Brussels: Complexe, 1987), 65-71.
} 
1955, but the negotiations on the future EEC remained very uncertain until September $1956 .{ }^{19}$ Later on, even after the signing of the Treaty of Rome in March 1957, a sword of Damocles hung over the EEC as France's financial difficulties threatened to make its implementation impossible. Paris seemed unable to fulfil the first liberalisation obligations which were scheduled for 1 January 1959.

In the meantime, the UK launched the FTA project. ${ }^{20}$ London's goal was both to continue the successful dynamic of the OEEC, and to avoid being isolated by a successful 'community Europe'. Its aim was to create a loose zone of commercial co-operation, a 'free trade area', in which goods could freely circulate. It was to be managed by intergovernmental institutions, and was to be extended to all the OEEC member states. The FTA benefited from a wide political consensus in Western Europe, as it appeared to be a logical complement to the EEC. Most European countries were not ready to commit themselves to such a demanding amount of co-operation as that proposed by the EEC. It was also the first time that the British government agreed to a plan of mutual tariff reduction in Europe without any linked agreement with the US (The OEEC commitment was less restricting as it concerned only quotas and not tariffs). ${ }^{21}$ In particular, Ludwig Erhard, the influential German Minister of Economics, considered that the FTA was more in tune with his liberal views than the EEC, whose semi-federal and semi-liberal features he disliked, especially if France did not open its market. $^{22}$

However, the FTA suffered from two obvious flaws, one technical and the other political, when compared to the EEC. First, its project was technically designed only with regard to British interests, without taking into serious consideration the main concerns of the other European states. ${ }^{23}$ In order to preserve the imperial preference system, for example, all agreements on agriculture and all tariff convergence programmes were banned, and such shortcomings were criticised by various actors during the negotiations. For example, the Ligue Européenne de Co-operation Économique (LECE), a European business organisation which promoted European co-operation on a free trade basis, found itself divided on the issue of the FTA. Its general secretary, the Belgian Lucien Sermon, studied the British project and pointed out its technical flaws, which were attributable to the lack of tariff harmonisation. ${ }^{24}$

Second, the political strategy of the UK, which was the main promoter of the FTA, was clumsy. To begin with, as it was difficult for Whitehall and the British government to reach a consensus on this path-breaking project, London was late in getting its act together, and it was only in November 1956, when the main elements of the compromise regarding the future EEC had been dealt with, that the British government united behind the FTA. ${ }^{25}$ Later on, in the spring of 1957, the British wanted to go to a step further by opening intergovernmental negotiations. However, the Six preferred to concentrate on the ratification of the Treaties of

\footnotetext{
${ }^{19}$ Bossuat, L'Europe des Français, 296; Milward, The Rise and Fall, 261.

${ }^{20}$ In particular, Milward, The Rise and Fall, 240-9; Kaiser, Using Europe, 61-87.

${ }^{21}$ Milward, The Rise and Fall, 240.

${ }^{22}$ Sabine Lee, 'German Decision-Making Elites and European Integration: German "Europalitik" during the Years of the EEC and Free Trade Area Negotiations', in Anne Deighton, ed., Building Post- war Europe: National Decision-Makers and European Institutions, 1948-63 (London, Palgrave Macmillan, 1995), 38-54; Camps, Britain, 169.

${ }^{23}$ Kaiser, Using Europe, 91, 94.

${ }^{24}$ Archives of the LECE (in Louvain-la-Neuve, Belgium), 653, note on a meeting of 2 Oct. 1957; note of Sermon, 24 Oct. 1957; on the LECE: Michel Dumoulin, Anne-Myriam Dutrieu, La Ligue Européenne de Coopération économique (1946-1981): Un groupe d'étude et de pression dans la construction européenne (Berne: Peter Lang, 1993).

${ }^{25}$ Kaiser, Using Europe, 78, 83; Milward, The Rise and Fall, 252, 262.
} 
Rome,${ }^{26}$ especially as it was the French National Assembly which caused the EDC's failure in 1954. Signed on 25 March 1957, the Treaty of Rome was quickly ratified during the summer and autumn of 1957, but intergovernmental negotiations on the FTA only began in October 1957, with a dedicated OEEC Committee chaired by Reginald Maudling, the British Paymaster General.

In addition, the British sometimes adopted too aggressive a stance towards the EEC. In March 1957, for example, the Foreign Secretary, Selwyn Lloyd, proposed a 'Grand Design', which was a vague project designed to revitalise European co- operation by submitting all European organisations to the OEEC. ${ }^{27}$ However, this clumsy attempt to control the EEC quickly failed. During the summer and autumn of 1957, London, supported by the countries of the Commonwealth, launched a GATT offensive against the EEC. ${ }^{28}$ It criticised the provisions of the Treaty of Rome concerning agriculture and the relationships between the EEC and its overseas territories - France and Belgium's colonies and former colonies. The Six were disappointed by this attitude as they clearly refused to accept any challenge to the Treaty of Rome, which in their opinion had to be preserved in its entirety. ${ }^{29}$

However, despite these difficulties, the FTA remained at the top of the European co-operation agenda throughout 1957 and 1958, in parallel with the negotiations on the implementation of the Treaty of Rome from 1 January 1959 onwards. As far as both these issues were concerned, the most problematic country was France.

\section{France from 1956 to 1958: Towards a Failed State?}

The situation in France deteriorated rapidly in two stages between 1956 and 1958. In the first stage, which lasted until mid-1957, France experienced economic difficulties which were obstacles to the imposition of its authority in the EEC and FTA negotiations. The basic problem stemmed from the fact that the French economy was traditionally more protectionist than that of most of its partners in Western Europe. ${ }^{30}$ In addition to this structural orientation, Paris suffered as a result of three specific problems from late 1956 onwards: the Suez crisis, the growing deployment of French troops in Algeria, and an economic policy based on an increasing level of public expenditure. ${ }^{31}$ This state of affairs resulted in the deepening of both the budget and trade deficits. These difficulties account for the fact that Paris was more reluctant to commit itself to free trade agreements such as the EEC or the FTA.

As regards the EEC, many French decision-makers displayed the utmost caution in their dealings with this organisation even before the signing of the Treaty of Rome in March 1957. As early as September 1956, for example, even before the Suez crisis of November 1956, the Minister for Finance and the Economy, Paul Ramadier, warned that France was not ready for

\footnotetext{
${ }^{26}$ AFFAM, DECE 622, note of 3 May 1957; DDF, 1957-I, 322, Bousquet's telegram to Pineau, 18 Apr. 1957.

${ }^{27}$ Kaiser, Using Europe, 99-100; Jeffrey Glen Giauque, Grand designs and visions of unity: the Atlantic powers and the reorganisation of Western Europe, 1955-1963 (London, University of North Carolina Press, 2002$), 51$.

${ }^{28}$ TNA, CAB 130/123, note on the meeting of 11 July 1957; DDF, 1957-II, 238, note DAEF, 2 Oct. 1957; DDF, 1957-II, 253, Chauvel's telegram to Pineau, 9 Oct. 1957; Lucia Coppolaro, Trade and Politics across the Atlantic: The European Economic Community (EEC) and the United States of America in the GATT Negotiations of the Kennedy Round (1962-1967) (Ph.D. thesis, European University Institute, 2006), 29.

${ }^{29}$ AFFAM, DECE 623, note on a meeting, 2 Oct. 1957.

${ }^{30}$ Frances Lynch, France and the International Economy: From Vichy to the Treaty of Rome (London: Routledge, 1997), 128-30; Moravcsik, The Choice, 108-15.

${ }^{31}$ AFFAM, 'Papiers directeurs Olivier Wormser' [hereafter POW] 78, folio 2, OEEC Council Secretariat, report on the economic situation, 25 March 1957.
} 
free trade because of the situation in Algeria. Instead, he stated that the country should prepare itself to become a 'closed economy' (économie fermée) or even a 'war economy' (économie de guerre). ${ }^{32}$ A large number of influential French decision-makers, moderate politicians such as Pierre Mendès-France and high-ranking civil servants in the Ministry of Finance and elsewhere, for example, were hostile to any free trade agreement. ${ }^{33}$ In May 1956, for example, Oliver Wormser, the senior French diplomat responsible for European economic issues, had sent a very hostile analysis of the Common Market negotiations to his minister. ${ }^{34}$ In April 1957, however, Wormser fully accepted the fact that the EEC was an unavoidable commitment as far as France was concerned. ${ }^{35}$ This development was linked to the concessions that France had succeeded in being granted in the Treaty of Rome. This meant that the pace of liberalisation could be easily slowed down, unfair competition controlled by the independent authority of the European Commission, financial transfers to colonies and former colonies of EEC member states (most of which were French) were scheduled, and agriculture benefited from special treatment. ${ }^{36}$

This situation illustrated the ambiguity of French policy towards the FTA. The need to conclude the FTA agreement was emphasised during the debate on the future Treaty of Rome in the French National Assembly. ${ }^{37}$ The British archives provide even more evidence of the French leaders' pro-British stance, with, for example, the French Prime Minister, Guy Mollet, telling Eden in September 1956 that 'he for his part would have liked to join the Commonwealth'. ${ }^{38}$ This statement gave rise to a great deal of discussion in Whitehall, even if one particular civil servant stressed the fact that Mollet was very vague and non-committal. ${ }^{39}$ Later on, in March 1957, the French Foreign Minister, Christian Pineau, suggested to Macmillan that bilateral trade negotiations should be launched even before the signing of the Treaty of Rome. ${ }^{40}$ This political support remained steady throughout 1957 and 1958 despite the fact that a constructive French position on the FTA proved to be impossible to establish. In Robert Marjolin's words, 'the FTA is politically necessary but economically impossible'. ${ }^{41}$

The French situation further deteriorated during a second stage, which began in mid-1957. In 1957, over 350,000 French soldiers were involved in the Algerian war of independence. ${ }^{42}$ This war increased the instability of the French political system as the decolonisation issue created internal divisions within the various political parties. There were no fewer than three French governments in 1957, and thus French officials were unable to make any commitments regarding the FTA during the first meeting of the Maudling Committee in

\footnotetext{
${ }^{32}$ FNA, F60, 3112, minutes of an interministerial meeting, 4 Sep. 1956.

${ }^{33}$ Warlouzet, Le choix de la CEE, 68-76.

${ }^{34}$ DDF 1956-I, 293, note from Olivier Wormser to Maurice Faure, 3 May 1956.

${ }^{35}$ AFMF, B 44.248, note from Wormser to La Genière, 29 Apr. 1957.

${ }^{36}$ See in particular the analysis of Wormser's service, the DAEF (Direction des affaires économiques et financières): DDF, 1956-III, 262, note from the DAEF, 5 Dec. 1956.

${ }^{37}$ On the debate of Jan. 1957: Année politique:1957 (Paris: PUF, 1958), 11.

${ }^{38}$ TNA, PREM/ 11/1352/22-5, 'Meeting at the Hotel Matignon, 27 Sep. 1956'.

${ }^{39}$ TNA, CAB 130/120, cabinet meeting 'Franco-British Union', 1 Oct. 1956; Milward, The Rise and Fall, 2569; TNA, PREM 11/1352, meeting 'Political Association with Europe', 4 Oct. 1956.

${ }^{40}$ TNA, FO 371/ 128338, Doc. 611/278, meeting at the Matignon, 9 Mar. 1957.

${ }^{41}$ Quoted in Bossuat, Faire l'Europe, 77. Marjolin was the leading French negotiator for the Treaty of Rome on economic issues, and the first important French Commissioner (1958-67).

${ }^{42}$ On the war in Algeria in 1955-57: Benjamin Stora, Histoire de la Guerre d'Algérie (1954-1962) (Paris: La Découverte, 1993), 20-30.
} 
October 1957 for the simple reason that at that particular time there was no French government. ${ }^{43}$ Meanwhile, the French financial and trade deficits deepened.

As France became the most reluctant actor in the FTA negotiations, Maudling tried to overcome the problem by concluding a treaty which included special treatment for France. ${ }^{44}$ This was dangerous as France risked isolation through being considered a country of secondary importance, unable to catch up with the most dynamic European countries and on a par with Greece or Portugal. However, France benefited from the creation of a new institution, the European Commission, in January 1958. The EEC Commission's ambitious German president, Walter Hallstein, decided to assert the EEC's influence in the FTA negotiations, although there was no consensus among the College of Commissioners for such involvement. ${ }^{45}$ Because of its technical criticisms of the FTA and its efforts to establish a consensus among the Six, the Commission helped to support the French position without giving any good reasons for the more unreasonable features of France's stance. Although the Commission was more moderate in its approach than the French, its role was seen as too hostile to the FTA not only by the British but also by some Germans, such as Erhard. ${ }^{46}$ These reactions demonstrated the importance of the Commission's involvement in the discussions, and explain why, from the spring of 1958, many British officials began to doubt that the FTA negotiations could ever be brought to a successful conclusion. ${ }^{47}$

In the meantime, Paris was systematically requesting the help of its partners. For example, France closed its markets by restoring the quotas which had previously been removed in June 1957. The OEEC gave its prior approval, but France remained under close supervision as this authorisation was only granted for an eighteen-month period until December $1958 .{ }^{48}$ At the 'Community Europe' level, the Treaty of Rome stipulated that the opening up of markets had to begin on 1 January 1959 with a lowering of intra-EEC customs duties. If France was unable to support this trade liberalisation process, it would find itself under the supervision of the EEC Commission, which would monitor the safeguard clauses, particularly through the application of articles 108 and 109 EEC. Lastly, at the international level, the French governments needed international support in order to help to cover France's deficit. The agreement came in January 1958, when large loans, mainly from the United States and Germany, were granted to France. However, these loans came attached with stringent conditions concerning the rebalancing of the French budget, such as pressure to limit the deployment of French troops in Algeria. ${ }^{49}$ French trade and financial difficulties were therefore a serious obstacle to French independence.

The final phase occurred after the French bombing of the Tunisian town of Sakiet, during which sixty-nine civilians were killed. ${ }^{50}$ This diplomatic incident provoked an international crisis, with France having not only to face accusations at the United Nations, but also to

\footnotetext{
${ }^{43}$ DDF, 1957-II, 288, telegram from Christian Pineau, 25 Oct. 1957.

${ }^{44}$ TNA, T 337/7, Record of a conversation between Reginald Maudling and Ludwig Erhard, 11 March 1958, and record of a conversation between Reginald Maudling and Paul-Henri Spaak, 13 Mar. 1958.

${ }^{45}$ EUA, reports of the Commission meetings, 5-6 March 1958 and 17 Mar. 1958.

${ }^{46}$ AFFAM, DECE 615/48, telegram from Wormser, 20 Mar. 1958; TNA, T 337/7, note on a meeting between Erhard, Maudling and Hallstein, 17 Feb. 1958; William Wallace, 'Walter Hallstein - Aus britischer Sicht', in Wilfried Loth, William Wallace and Wolfgang Wessels, eds, Walter Hallstein: The Forgotten European (Bonn: Europa Union Verlag, 1995), 237; Camps, Britain, 148-50.

${ }^{47}$ Camps, Britain, 146; Milward, The Rise and Fall, 284-6; Ellison, Threatening Europe, 195-6, $203-5$.

${ }^{48}$ AFFAM, POW 78/97, decisions of the OEEC Council, 22 Nov. 1957.

${ }^{49}$ AFMF, B 48875, note of 15 Feb. 1958.

${ }^{50}$ On the 1958 events in Algeria: Stora, Histoire, 47-51.
} 
accept an international arbitration mission. ${ }^{51}$ As a result, the government fell. On 13 May 1958, Pierre Pflimlin, a moderate politician, was due to become head of the French government. That same day, French settlers rioted in Algiers and seized power with the support of the army. In a context of growing rumours of a coup d'état in Paris, led by the armed forces, the French National Assembly accepted the nomination of Charles de Gaulle as Prime Minister (Président du Conseil) on 1 June 1958.

At the same time, the crisis sparked off a serious monetary crisis, which forced France to take measures to close its markets. As Paris had not respected its obligations under the Treaty of Rome - it was supposed to ask for the approval of the EEC institutions before closing its markets - the European Commission placed France under close scrutiny. In June 1958, the new supranational body even forced the de Gaulle government to abandon several additional measures concerning import restrictions that had already been planned. ${ }^{52}$

In conclusion, in June 1958, France, although in theory one of the most powerful European countries, seemed unable to fulfil her commitment to European co- operation, either at the EEC or the 'Greater Europe' scale of the OEEC and FTA projects. The contrast between France and its neighbours was striking. Whereas most of the western European democracies had completed their post-war reconstruction, France was still dependent on foreign loans and bogged down in colonial wars. Moreover, in May 1958 its government had no authority over its army. Paris was constrained by numerous international obligations, from the financial (loans of January 1958), trade (OEEC and EEC), and political (UN) standpoints. However, de Gaulle soon managed to restore French international influence.

\section{De Gaulle's Involvement in the FTA Negotiations}

De Gaulle established a coherent twofold strategy as early as the summer of $1958 .{ }^{53}$ First, at the national level, the restoration of French authority was of the utmost priority. De Gaulle tackled the financial and trade crises in addition to instigating institutional reforms and resolving the colonial problem. He set up a special committee entrusted with the preparation of an ambitious reform plan, the Rueff Plan, which was based on a three-point programme: the devaluation of the franc, budget austerity and the opening up of the French market. ${ }^{54}$ These bold reforms were meant to break with the protectionist past and to allow France to fulfil its international commitments.

Second, at the European level, de Gaulle deliberately chose to support the EEC and not the FTA. This came as a surprise as in June 1958 many Western analysts thought that de Gaulle

\footnotetext{
${ }^{51}$ Martin Thomas, 'France accused: French North African Policy before the United Nations, 1952-1962', Contemporary European History, 10, 1 (2001), 109-10.

${ }^{52}$ EUA, report of the Commission meeting, 11 June 1958; AFFAM, PA-AP 314-1, report of the meeting of 10 June 1958.

${ }^{53}$ On the main features of de Gaulle's foreign policy in 1958: Maurice Vaïsse, La Grandeur: Politique étrangère du général de Gaulle, 1958-1969 (Paris: Fayard, 1998), 22-52; Georges-Henri Soutou, L'alliance incertaine: Les rapports politico-stratégiques franco-allemands, 1954-1996 (Paris: Fayard, 1996), 123-30; Jeffrey Vanke, 'Charles de Gaulle's Uncertain Idea of Europe', in Desmond Dinan, ed., Origins and Evolution of the European Union (Oxford: Oxford UP, 2006), 141-50. Thereafter Vanke, 'Charles de Gaulle'.

${ }^{54}$ On the Rueff Plan, see mainly Olivier Feiertag, Wilfried Baumgartner: Un grand commis des finances à la croisée des pouvoirs (1902-1978) (Paris: CHEFF, 2007), 555-96; Warlouzet, Le choix de la CEE, 172-85; Lynch, 'De Gaulle', 119-20, 133-5.
} 
would raise doubts about the French commitment to the EEC. ${ }^{55}$ In addition to the arguments, such as economic modernisation, political domination of a 'Little Europe', and the containment of Germany, which are usually advanced to explain this decision, ${ }^{56}$ de Gaulle's choice was based on a fundamental underestimation of EEC institutions. Looking at the example of the ECSC, which, he considered, 'had not brought about any decisive change', he thought that the EEC institutions would be ineffectual. ${ }^{57}$

However, France needed to act as a reliable partner in the FTA negotiations in order to enable the EEC to become fully operational. In February, the Gaillard government had adopted a memorandum on the FTA which set out a very reluctant French position towards the organisation. ${ }^{58}$ In early July 1958, the de Gaulle government adopted a new position which relinquished two major French requests concerning a three-year delay between the official establishment of the EEC, which had to come first, and that of the FTA, and a refusal to commit France to a full-scale free trade area. ${ }^{59}$ Moreover, instead of requesting an FTA modelled on the EEC, France accepted a minimalist FTA based on the British plan, which, for instance, did not include any provisions for agriculture, but which sought discussion on sectoral measures concerning industrial products. The idea was to take advantage of the numerous sectoral provision-related requests that were being made by various governments and interest groups, and to delay the establishment of the FTA. French involvement in the FTA project was therefore now fully accepted.

This new development was welcomed by France's European partners. ${ }^{60}$ The FTA appeared to have been relaunched. This renewed French credibility allowed de Gaulle to reinstitute a strong Franco-German alliance during a meeting with Adenauer in September 1958. ${ }^{61}$

It is, however, important to stress two points in connection with traditional publications on the FTA. First, agriculture played absolutely no role in these negotiations. The main issue underlying the unrealistic nature of the French memorandum of February 1958, and the credibility of the new French position of July 1958, was commitment to the liberalisation of industrial products. ${ }^{62}$ The French government's objectives with regard to European integration and agriculture were still very vague in 1958, as was demonstrated, for example, during the Stresa conference on agriculture in July $1958 .{ }^{63}$ Second, it is impossible to assert that de Gaulle had always rejected the FTA because no direct sources exist to support this claim due to the fact that papers either written by de Gaulle or quoting him are rare. Minutes of a meeting of 10 June 1958 simply state that the EEC became the priority issue. ${ }^{64}$ More

\footnotetext{
${ }^{55}$ Ellison, Threatening Europe, 198; Giauque, Grand designs, 36, 83; Hubert Zimmermann, Money and Security: Troops, Monetary Policy and West Germany's Relations to the United States and the United Kingdom, 1950-1971 (Cambridge: Cambridge University Press, 2002), 82.

${ }^{56}$ Vanke, 'Charles de Gaulle', 148-9.

${ }^{57}$ AFFAM, PA-AP 314/1, note on an interministerial meeting, 10 June 1958; note for the Ministry of Foreign Affairs, 13 Aug. 1958, in Charles de Gaulle, Lettres, notes et carnets: Juin 1958-décembre 1960 (Paris: Plon, 1985), 73.

${ }^{58}$ FNA, 1977.1471/61, note on an intergovernmental meeting of the 20 Feb. 1958.

${ }^{59}$ AFFAM, DECE 753/284, note from François Valéry, 12 July 1958.

${ }^{60}$ AFFAM, DECE 743, note DAEF, 30 July 1958.

${ }^{61}$ DDF 1958-II, 155, minutes of the discussion between de Gaulle and Adenauer on 14 Sep. 1958; Soutou, L'alliance incertaine, 137-46.

${ }^{62}$ Warlouzet, Le choix de la CEE, 132-9, 149-56.

${ }^{63}$ Ann-Christina Knudsen, Farmers on Welfare: The Making of Europe's Common Agricultural Policy (Ithaca and London: Cornell UP, 2009), 128.

${ }^{64}$ AFFAM, PA-AP 314-1, report of the meeting of 10 June 1958.
} 
strikingly, the French archives of August 1958 reveal an internal conflict between anti-FTA activists - these included most French civil servants and businessmen - and Wormser, who was de Gaulle's most influential advisor on European economic issues. ${ }^{65}$ Wormser tried to develop a friendlier approach towards the FTA. In August 1958, for example, he complained to Goetze, de Gaulle's economic advisor, that the Minister of Industry was still reluctant and did not really want to become involved in the sectoral negotiations because of the opposition of French business interests to the FTA. ${ }^{66}$ To be fair, it is important to mention that the official French instructions did not mention the need for the rapid signing of an FTA treaty. It was stated that the French should participate 'constructively', and in a 'co-operative' way, but that they should also try to delay the conclusion of the negotiations. ${ }^{67}$ De Gaulle's aim was to postpone any finalisation of the FTA until after 1 January 1959 in order to establish the preeminent position of the EEC. It was only then that it would be possible to establish the FTA, with its many sectoral exceptions, as long as it posed no threat to the EEC.

\section{British Errors and the Failure of the FTA}

Strategic errors committed by the British were the deciding factors in de Gaulle's pulling out of the FTA negotiations. In London, the situation became more complex in mid-1958 as the British government were pursuing two parallel strategies. On the one hand, the UK wanted to follow the 'Greater Europe' approach established with the FTA in the autumn of 1956, but, on the other hand, an earlier strategy for an international solution re-emerged in the summer of 1958. This was based on the UK's traditional role as a world power, symbolised by the role of sterling as an international currency, and by international trade liberalisation. ${ }^{68}$ In this respect, the FTA was less useful if trade liberalisation occurred at an international level, presumably through GATT. The British Prime Minister, Harold Macmillan, remained firmly committed to the FTA nevertheless, and was even tempted to take radical retaliatory measures, such as a tariff war, or the withdrawal of British troops from NATO, if the FTA negotiations failed. ${ }^{69}$ However, Macmillan's aggressiveness revealed his lack of a coherent strategy as well as his overestimation of British power, especially when the USA's strong support for the EEC and for international liberalisation was taken into consideration. ${ }^{70}$ The unfeasibility of Macmillan's proposals was clearly demonstrated by the highly critical response from Whitehall regarding this strategy of retaliation. ${ }^{71}$

This lack of coherent British strategy enabled the French to change their policy, with Wormser advocating more aggressive tactics in the FTA negotiations from October $1958 .{ }^{72}$

\footnotetext{
${ }^{65}$ His influence was based on his friendship with Maurice Couve de Murville, de Gaulle's long-standing minister for Foreign Affairs: Robert Marjolin, Le travail d'une vie: Mémoires 1911-1986 (Paris: Robert Laffont, 1986), 258, 311; Henri Froment-Meurice, Vu du Quai : Mémoires 1945-1983 (Paris, Fayard, 1998), 303.

${ }^{66}$ AFFAM, POW 40/134, note from Wormser to Goetze, 22 Aug. 1958; POW 40/162, note from Wormser to Couve de Murville, 11 Sep. 1958.

${ }^{67}$ AFFAM, DECE 754/157, note from Maurice Ulrich, 3 Nov. 1958; AN/1977.1471/63, report of a meeting of 30 Oct. 1958.

${ }^{68}$ TNA, T 230/373, note on a meeting chaired by the Chancellor of the Exchequer, 6 March 1958; BNA, PREM 11/2671, 180-2, memorandum of the Chancellor of the Exchequer, 8 Sep. 1958.

${ }^{69}$ TNA, T 234/378/50, letter from Macmillan to the Foreign Secretary, 15 Oct. 1958.

${ }^{70}$ Giauque, Grand designs, 39.

${ }^{71}$ TNA, T234/378/55, note for the Chancellor of the Exchequer, 16 Oct. 1958; TNA, T234/378/102, note from the Chancellor of the Exchequer to the Prime Minister, 31 Oct. 1958.

${ }^{72}$ AFFAM, POW 40/189, note from Wormser, 4 Oct. 1958; DDF, 1958-II, 225, note from Wormser, 6 Oct. 1958.
} 
Finally, the French and British clashed on 14 November 1958. After an equivocal statement on the FTA by Jacques Soustelle, a junior French minister, Maudling decided to suspend the discussions. The French government immediately seized this opportunity to announce the termination of the negotiations. ${ }^{73}$ Historians have generally interpreted this episode as resulting from Maudling's clumsiness, ${ }^{74}$ with the British negotiator reacting too strongly to French pressure. The British archives confirm this interpretation as Maudling was forced to justify his action to German officials. ${ }^{75}$ After this event, Macmillan was still undecided as to which strategy to follow. Numerous options were studied, but none was implemented. ${ }^{76}$

In the meantime, de Gaulle succeeded in bringing the FTA negotiations to an end by making it possible for the EEC to be fully implemented. Thanks to the Rueff Plan, France was able to catch up with the trade and currency liberalisation process. ${ }^{77}$ Adenauer and de Gaulle reached an agreement on European issues on 26 November $1958 .{ }^{78}$ Cold-War-related factors, such as the difficult London-Bonn negotiations on British troops in Germany, and de Gaulle's strong and prompt support of the Federal Republic of Germany during the Berlin crisis, were also important. ${ }^{79}$ The Six took up a common position on the EEC on 3 December $1958{ }^{80}$ It was based on the full implementation of the Treaty of Rome by the Six without any recourse on the part of France to the safeguard clauses, and on measures to open up the EEC market to foreign imports from GATT member states. This latter measure was intended to avoid any accusation that the Six were building a 'Fortress Europe'. The promotion of co-operation with GATT also contributed to the undermining of the OEEC/FTA framework.

In late December 1958, the Rueff Plan was implemented, and the French franc followed the main western European currencies' general return to convertibility on 1 January $1959 .{ }^{81}$ There was close co-operation between the central banks of France, Germany and the UK during this process. ${ }^{82}$ After this agreement, the FTA project was hardly discussed during the first six months of 1959 and thereafter was completely abandoned. ${ }^{83}$ Meanwhile, the EFTA project was launched and rapidly negotiated, with the Stockholm Convention being signed on 4 January 1960. However, such an accord was only second-best for London and its partners.

The end of the FTA negotiations demonstrated Macmillan's inability to find a coherent way of simultaneously achieving his European and international ambitions. In contrast, de Gaulle's coherent strategy succeeded: internal stability in France was restored, the EEC was strengthened and the FTA was rejected.

\footnotetext{
${ }^{73}$ DDF, 1958-II, 344, telegram from the French Foreign Minister, Couve de Murville, 20 Nov. 1958; DDF, 1958-II, 334, letter from de Gaulle to Macmillan, 15 Nov. 1958.

${ }^{74}$ Milward, The Rise and Fall, 290-91; Lynch, 'De Gaulle', 131.

75 TNA, T 337/7, note from J. E. Coulson, 17 Nov. 1958.

${ }^{76}$ TNA, CAB 130/123/33-6, meeting chaired by the Prime Minister, 27 Nov. 1958.

${ }^{77}$ Lynch, 'De Gaulle', 133-5.

${ }^{78}$ DDF, 1958-II, 370, report on the Franco-German discussion, 26 Nov. 1958.

${ }^{79}$ Zimmermann, Money, 70, 79; Georges-Henri Soutou, La Guerre de Cinquante ans: Les relations Est-Ouest (Paris: Fayard, 2001), 375.

${ }^{80}$ DDF, 1958-II, 389, telegram from Couve de Murville, 4 Dec. 1958; AFFAM, RPUE 32, meeting of the EEC Council, 3 Dec. 1958, note of 30 Dec. 1958.

${ }^{81}$ Jacob J. Kaplan, Günther Schleiminger, The European Payments Union: Financial Diplomacy in the 1950s (Oxford: Clarendon Press Oxford, 1989), 317.

${ }^{82}$ Monika Dickhaus, 'Facing the Common Market: The German Central Bank and the Establishment of the EEC, 1955-58', Journal of European Integration History, 2, 2 (1996), 106.

${ }^{83}$ Bossuat, L'Europe des Français, 396-8.
} 


\section{Conclusion: Lessons of the FTA Project}

The FTA negotiations exemplify the need for historians to study failures as well as successes. More precisely, they resulted in three turning points in the history of Franco-British relationships, in the history of Europe, and as regards de Gaulle's position as a 'Father of Europe'.

To begin with, Franco-British relationships were at a turning-point. Macmillan's willingness not only to reach agreement on the FTA regardless of France's difficulties, but also to envisage harsh retaliatory measures, was especially significant. This situation left some French officials confused. In early 1956 for instance, the leading French FTA negotiator, Olivier Wormser, was a European integration sceptic. He was close to René Massigli, the famously pro-British French ambassador to the UK (1944-55). ${ }^{84}$ In the summer of 1956, Wormser was replaced as chief negotiator because of his anti-European integration stance, ${ }^{85}$ but he became more favourable to European integration in 1957, prompted not by idealism but by rational calculation. After two years of difficult negotiations with the British, he became one of the staunchest defenders of the Gaullist vision of European integration based on a 'Core Europe' dominated by France and excluding the UK. The experience of the FTA is thus very important in any attempt to understand the hostility of French Gaullist officials towards the UK from 1958 to $1969 .{ }^{86}$ The FTA negotiations were also an indication of certain features of the first British application to join the EEC, especially that of France's ability to make use of Germany and the Commission's lack of enthusiasm for an awkward Macmillan. ${ }^{87}$ Wormser also used recollections of the FTA negotiations to criticise London during the negotiations on the first application. ${ }^{88}$

The FTA was an important project in terms of European co-operation, despite its failure, because it was an indication of the UK's willingness to become involved in European cooperation. The FTA was not doomed to failure from the beginning: in early 1958, if it had not been for the European Commission's lack of support and the dramatic events that took place in France in May 1958, an agreement could have been reached, and France would have been left in the position of a country reliant on external assistance. In the summer of 1958, de Gaulle seriously considered the possibility of coming to an agreement on the FTA, albeit in 1959 and with many sectoral exceptions. Lastly, the agricultural issue played only a secondary role in these negotiations, the main concern of which was the trade liberalisation of industrial goods.

Furthermore, the FTA corresponded not only to British interests but also to a more general concept of a 'Free Trade Europe', which found widespread support in Northern Europe. The UK and the Scandinavian countries shared a cultural preference for a loose form of co-

\footnotetext{
${ }^{84}$ Raphaële Ulrich-Pier, 'René Massigli (1888-1988): Une vie de diplomate' (Ph.D. thesis, University of Paris I, 2003), 1012-13.

${ }^{85}$ Hanns Jürgen Küsters, Fondements de la CEE (Luxembourg: Office de Publication des Communautés, 1990), 186.

${ }^{86}$ Laurent Warlouzet, 'Le Quai d'Orsay face au Traité de Rome: la direction des affaires économiques et financières (DAEF) de 1957 à 1975', in Laurence Badel, Piers Ludlow and Stanislas Jeannesson, eds, Les administrations nationales face aux défis européens du vingtième siècle (Brussels: Peter Lang, 2006), 160-7.

${ }^{87}$ Piers Ludlow, Dealing with Britain: The Six and the First UK Application to the EEC (Cambridge: Cambridge UP, 1997), 245-50.

${ }^{88}$ Piers Ludlow, 'Diplomacy With Different Rules: Learning to Negotiate in the EEC', in Marie- Thérèse Bitsch, Raymond Poidevin, Wilfried Loth, eds, Institutions européennes et identités européennes (Brussels: Bruylant, 1998), 246.
} 
operation, which was less supranational than the EEC and more free-market in scope. ${ }^{89}$ The FTA was thus a forerunner not only of the EFTA but also of the concept of European integration that was later to be defended by several member states. Both the UK and Denmark, for example, belonged to the 'Luxembourg Compromise Club', which made extensive use of the veto in the early 1980s. ${ }^{90}$

Lastly, the FTA was important as it enabled de Gaulle to act as a real 'Father of Europe'. Even before de Gaulle returned to power, the FTA provided an incentive for the young European Commission to assert itself by playing a constructive role in the negotiations. In addition, de Gaulle greatly strengthened the EEC, as the French president succeeded in terminating the FTA negotiations only because he had found a solution within the EEC framework. Without the EEC, France would certainly have been forced to conclude an FTA agreement in 1958. Conversely, without de Gaulle, the EEC would probably have been diluted into a larger FTA, which would have been reduced to a loose agreement between member states.

As a result, de Gaulle can certainly be associated with the title 'Father of Europe'. Robert Frank stated that the title of 'Father of Europe' incorporates several features. ${ }^{91}$ De Gaulle did not fully qualify for two of them, Atlanticism and European idealism, although he remained firmly committed to the Atlantic Alliance and presented a very proactive vision of Europe. Indeed, as he did not discuss European integration issues from 1955 to May 1958, it is frequently forgotten that de Gaulle regularly referred to European co-operation in his speeches between 1947 and $1954 .{ }^{92}$ He developed an ambitious vision, which was mostly intergovernmental but which accepted limited federal features, and he even pleaded the case for Europe-wide referenda. Later on, in the 1960s, he combined vocal opposition to supranational institutions with pragmatic day-to-day co-operation with them when it served French interests to do so. ${ }^{93}$

Moreover, the French leader fulfils all the other criteria which define the 'Father of Europe'. These criteria encompass such concepts as paternity (having created something), international experience, cultural openness towards his European neighbours, anti-fascism credentials, Christian humanism, and mixed feelings towards the 'Greater Europe' of the OEEC. As one of the main promoters of the EEC, an organisation whose success was highly uncertain in 1957 and 1958, de Gaulle does indeed deserve the title of 'Father of Europe'. However, this does not mean that he was not later disappointed by the European integration process in the 1960s. De Gaulle, as is the case with all individual actors, was not able to control the long-

\footnotetext{
${ }^{89}$ Wolfram Kaiser, "Culturally Embedded and Path-Dependent: Peripheral Alternatives to ECSC/EEC "Core" Europe', Journal of European Integration History, 7, 2, 2001, 11-36.

${ }^{90}$ Fiona Hayes-Renshaw and Helen Wallace, 'Changing the Course of European Integration - or Not?', in JeanMarie Palayret, Helen Wallace and Pascaline Winand, eds, Visions, Votes and Vetoes: The Empty Chair Crisis and the Luxembourg Compromise Forty Years On (Brussels: Peter Lang, 2006), 312-14.

${ }^{91}$ Frank, 'Les pères'; see also Antonin Cohen, 'Le "père de l'Europe": la construction sociale d'un récit des origines', Actes de la recherche en sciences sociales, 2007, 166, 14-29.

${ }^{92}$ Edmond Jouve, Le général de Gaulle et la construction de l'Europe (1940-1966) (Paris: LGDJ, 1967), 14-5, 26-7, 248-9.

${ }^{93}$ Piers Ludlow, 'From Words to Actions: Reinterpreting de Gaulle's European Policy', in Christian Nuenlist, Anna Locher and Garret Martin, eds, Globalising de Gaulle: International Perspectives on French Foreign Policies, 1958-1969 (Plymouth: Lexington Books, 2010), 79.
} 
term consequences of his decisions. ${ }^{94}$ He can thus be considered to be a 'Father of Europe', albeit of a more supranational Europe than he had actually intended.

${ }^{94}$ On this interpretation of European integration history, see Laurent Warlouzet, The Rise of European Competition Policy, 1950-1991: A Cross-Disciplinary Survey of a Contested Policy Sphere (Florence: European University Institute Working papers, 2010. 